\title{
METODE SLOW SAND FILTER DAN PENGUKURAN MPN COLIFORM SEBAGAI UPAYA PENINGKATAN KUALITAS AIR SUNGAI DI PEKAPURAN RAYA BANJARMASIN
}

\author{
Sri Herlina ${ }^{1}$ \\ ${ }^{1}$ Program Studi Pendidikan Dokter, Fakultas Kedokteran \\ Universitas Islam Malang \\ (Email: $\underline{\text { ilinskm@gmail.com) }}$
}

\begin{abstract}
ABSTRAK
Sungai Pekapuran Raya Banjarmasin merupakan salah satu kawasan pinggiran sungai yang padat penduduk, saat musim kemarau kondisi sungai terlihat dangkal dipenuhi tumpukan sampah, berwarna kecoklatan dan keruh. Penelitian ini bertujuan untuk mengukur MPN Coliform air sungai Pekapuran Raya dan melakukan pembinaan pada kelompok ibu Antasan Segra tentang peningkatan kualitas air sungai menggunakan metode slow sand filter (SSF). Desain penelitian adalah observasional analitik dengan pendekatan cross sectional, melibatkan 38 responden secara total sampling. Teknik pengumpulan data dan analisis masalah dilakukan dengan pendekatan PRA (Participation Rural Appraisal). Bahan yang digunakan dalam pengolahan air menggunakan metode SSF seperti pasir, arang aktif, sabut kelapa (Ijuk) dan batu koral/kerikil serta busa penyangga yang tersedia cukup banyak disekitar rumah warga. Hasil pengukuran MPN Coliform pada air sungai Pekapuran Banjarmasin menunjukkan positif terdapat bakteri Coliform sebesar > 240/100 ml sampel, sedangkan ambang baku mutu yang dipersyaratkan yaitu $100 \mathrm{sel} / 100 \mathrm{ml}$ air.

Analisis kualitas air secara fisik menggunakan slow sand filter menunjukkan tingkat kekeruhan air sungai dari berwarna kecokelatan menjadi bening setelah penyaringan, model ini memudahkan masyarakat memanfaatkan air sungai menjadi air bersih karena lebih sederhana, murah, serta aman.
\end{abstract}

Kata Kunci : Metode slow sand filter, Air sungai, MPN Coliform.

\begin{abstract}
Pekapuran Raya Banjarmasin's river is one of coastal river area region that compact of society, at the dry season river condition looks shallow full of garbage stock, brown colour and muddy. This research aims to measure MPN Coliform the water of Pekapuran Raya river and coaching group of mother Antasan Segra about improving river water quality using slow sand filter (SSF) method. The research's design was analytic observational with cross sectional approach, involving 38 respondents in total sampling. Data completion technique and problem analysis were done with PRA approach (Participation Rural Appraisal). The Meterial that used in water processing was using SSF method such as sand, activated charcoal, coconut fiber (Ijuk) and coral/gravel and foam buffer thate available quite a lot around the house residents. The result of MPN Coliform measurement on Pekapuran Raya river Banjarmasin positive there is
\end{abstract}


bacterium > 240/100 $\mathrm{ml}$ sample, while the standar quality threshold requires 100 sel/100 ml air.

Physical water quality analysis by looking at the color change after processing using slow sand filter shows the turbidity level of brown colour water become clear after filtering, this model can processed by utilizing river water into clean air because it is more simple, cheap, and safe for the community.

Keywords: Method of slow sand filter, River water, MPN Coliform.

\section{PENDAHULUAN}

Banjarmasin merupakan salah satu wilayah dengan slogan Kota Seribu Sungai, memiliki penduduk berjumlah 625.395 jiwa dengan luas wilayah 72,6 $\mathrm{km}^{2}[1,2]$. Kondisi sungai saat ini cukup memprihatinkan disebabkan adanya kebiasaan penduduk yang membuang sampah secara langsung ke sungai menyebabkan air sungai semakin kotor keruh, berbau, berwarna kehitaman dan dangkal [3], kendala lain yang dirasakan masyarakat saat musim kemarau yaitu terganggunya jalur transportasi pedagang yang memanfaatkan air sungai menuju ke Pasar Binjai diwilayah tersebut, akibat dangkalnya sungai. Perilaku masyarakat menggunaan air sungai untuk konsumsi dan kebutuhan sehari-hari termasuk membuang kotoran biologis dan non biologis memicu tumbuh kembangnya kuman penyebab diare cepat berkembang dan menular melalui air yang tercemar [3],dan gangguan pencernaan yang berbahaya bagi kesehatan masyarakat.

Data kesehatan menunjukan lebih dari 150.000 orang yang masih memanfaatkan atau mengandalkan air untuk keperluan sehari-hari seperti memasak, cuci, dan kakus (MCK), terutama masyarakat yang bermukim di daerah pinggiran sungai [5]. Laporan Dinas Kesehatan Provinsi Kalimanan Selatan menunjukan bahwa penyakit diare di Banjarmasin sebesar 20,15\% atau 4632 kasus dari jumlah penduduk [6]. Berdasarkan hasil kajian Badan Lingkungan Hidup Daerah Banjarmasin tahun 2007 dan Balai Teknik Kesehatan Lingkungan Banjarmasin 2004 menyebutkan bahwa tingkat pencemaran sungai oleh zat kimia, biologi (kuman), dan sampah pada badan air semakin meningkat [3], seperti Sungai Alalak yang tercemar zat mangan $(165 \mathrm{mg} / \mathrm{l}$ lebih tinggi dari standart air kelas 1 yakni 0,1mg/l) dan Sungai Pekapuran oleh sampah dan tinja.

Penelitian yang dilakukan oleh Fakultas MIPA Universitas Lambung Mangkurat 2007 terhadap sungai Martapura, ditemukan bahwa bakteri Eshericia coli sebanyak 1,6 juta per $100 \mathrm{ml}$ air. Jumlah ini melebihi dari ambang baku mutu yang dipersyaratkan untuk air bersih yaitu 100 sel/100 mili liter air [5], oleh sebab itu pentingnya upaya perubahan perilaku hidup sehat dan bersih yang diterapkan pada masyarakat, tidak hanya dari kebiasaan BAB langsung kesungai tetapi juga menghindari resiko bahaya penggunaan air sungai untuk keperluan sehari-hari.

Rendahnya kesadaran masyarakat terutama keluarga dan anak-anak disepanjang sungai untuk menjaga lingkungan dari pencemaran air penting diberikan melalui kegiatan penyuluhan dan pendidikan kesehatan. Kebanyakan anak gemar bermain disungai yang dangkal dan kotor terutama saat kemarau panjang sehingga banyak tumpukan sampah yang tergenang dipermukaan sungai, mereka beranggapan hal tersebut tidak membahayakan bagi kesehatan dirinya. Laporan kesehatan setempat tercatat sebanyak 207 kasus diare ditahun 2011. 
Resiko terjangkitnya kuman atau bakteri dari air sungai dapat menimbulkan penyakit berbahaya seperti diare, disentri, gatal-gatal, kudis, kurap bahkan cedera atau kecelakaan akibat bekas bling kaca yang dibuang kesungai atau tumpukan sampah yang laut terbawa arus sungai juga berbahaya bagi anak yang mandi disungai tersebut [4].

Usaha pemerintah kota terkait dengan meningkatkan taraf hidup masyarakat, telah banyak dilakukan. Salah satu penggalakkan terfokus pada masalah lingkungan hidup, dalam hal ini penanganan sampah dan perbaikan pemukiman dibantaran sungai serta himbauan larangan membuang sampah disungai sudah dilakukan. Namun, usaha tersebut seringkali tidak didukung sepenuhnya oleh masyarakat sebagai fasilitator penggerak perbaikan kondisi lingkungan sungai.Tindakan intervensi terpadu untuk melakukan pengendalian perilaku tersebut yaitu melalui gerakan kesadaran masyarakat khususnya kelompok ibu dalam pengendalian pencemaran air dan pengolahan air sungai menggunkan metode slow sand filter. Pelaksanaan pengukuran kualitas air seperti MPN Coliform penting dilakukan sebagai upaya meningkatkan kualitas fisik dari air sungai sehingga angka kejadian diare pada balita semakin menurun dan mengurangi beban pencemar sungai, semakin hari semakin bertambah akibat buangan sampah dari masyarakat sekitar.

\section{METODE PENELITIAN}

Penelitian dilakukan secara observasional Analitik menggunakan pendekatan cross sectional [7]. Populasi dan Sampel dari penelitian ini adalah kelompok Ibu-ibu Antasan Segra sebanyak 38 responden secara total sampling. Teknik pengumpulan data yaitu metode Participation Rural Appraisal (PRA) diterapkan untuk pelaksanaan kegiatan pembinaan kelompok Ibu Antasan segera agar mampu menganalisis permasalahan yang terjadi dimasyarakat. Salah satunya model gerakan pembinaan masyarakat yakni pengolahan air sungai menggunakan metode slow sand filter. Media pengolahan air ini memanfaatkan bahan disekitar rumah warga seperti, pasir, arang aktif, sabut kelapa (ijuk), busa dan kerikil. Penelitian dilakukan di wilayah Antasan Segra Kelurahan Pekapuran Raya, Kecamatan Banjar Timur Kota Banjarmasin. Pemeriksaa Kualitas Air secara biologi yaitu MPN Coliform dilakukan dilaboratorium Mikrobiologi Fakultas Kedokteran Universitas Lambung Mangkurat Banjarbaru.

\section{Bahan dan Peralatan}

Bahan yang digunakan dalam penelitian ini adalah air sungai Antasan Segra Pekapuran Banjarmasin sebagai sampel air sungai, Media pengolahan air menggunakan koral, busa, ijuk, pasir, Arang aktif/karbon aktif, kerikil, kayu, besi, serok (pengki), pegas, cat, alat sedangkan

Alat yang dipergunakan dalam program ini adalah Cashingslow sand filter ukuran $50 \times 25 \times 25 \mathrm{~cm}$, ilet (kran), ember, pipa (selang) dan corong, sedangkan peralatan tabung reaksi (7 buah), tabung durham (7 buah), Autoclave, Laminaryflow, Pipet ukur, Aspirator, Inkubator, Spiritus atau bunsen, Ose, korek api, kapas Alkohol 70\%, Larutan Lactose Broth Double Strength (LBDS), Larutan Lactose Broth Single Strength (LBSS), Larutan Brilliant Green Lactose Broth (BGLB). 


\section{Cara pengukuran MPN Coli dan Metode Slow Sand Filter}

\section{Pengukuran MPN Coliform}

Mencuci tangan terlebih dahulu dengan menggunakan alkohol $70 \%$. Menyiapkan 5 tabung reaksi yang didalamnya terdapat tabung durham dan larutan Lactose Broth Double Strength (LBDS) serta 2 tabung reaksi yang didalamnya terdapat tabung durham dan Larutan Lactose Broth Single Strength (LBSS). Seluruh tabung ini terlebih dahulu dimasukan kedalam autoclave. Kemudian meletakkan ke 7 tabung reaksi tersebut kedalam laminary flow untuk sterilisasi. Memasukkan sampel air kran sebanyak $10 \mathrm{ml}$ ke 5 tabung reaksi yang berisi LBDS dengan menggunakan pipet ukur dan aspirator. Memasukkan sampel air kran sebanyak $1 \mathrm{ml}$ ke 1 tabung reaksi yang berisi LBSS dan $0,1 \mathrm{ml}$ ke 1 tabung reaksi yang berisi LBSS dengan menggunakan pipet ukur dan aspirator. Memasukkan semua tabung reaksi kedalam inkubator pada suhu $37^{\circ} \mathrm{C}$ selama 24 jam. Setelah 24 jam semua tabung reaksi di inkubasi, tabung dikeluarkan dari inkubator kemudian dimasukkan kedalam laminary flow. Perhatikan semua tabung, apabila terdapat gelembung udara pada tabung durham maka hasilnya positif, sedangkan apabila tidak terdapat gelembung udara pada tabung durham maka hasilnya negatif.

\section{Apabila hasilnya positif maka penelitian dilanjutkan ke tahap BGLB.}

a. Perhatikan semua tabung (ragam 5:1:1), apabila terdapat gelembung udara didalam tabung durham maka hasilnya positif mengandung kuman. mengambil tabung reaksi yang berisi 1 Larutan Brilliant Green Lactose Broth (BGLB) dan tabung durham, letakkan sesuai dengan urutan tabung MPN yang positif mengandung kuman.

b. Fiksasi mulut tabung yang positif, Sterilkan ose dengan nyala spiritus sampai pijar, kemudian diamkan ose beberapa saat sampai pijar menghilang.

c. Ambil kuman dari tabung MPN dengan ose kemudian masukkan ke dalam tabung BGLB yang sudah difiksasi terlebih dahulu.

d. Fiksasi tabung BGLB kembali dan tutup menggunakan kapas.

e. Masukkan tabung BGLB ke dalam inkubator selama 24 jam pada suhu $37^{\circ} \mathrm{C}$.

f. Sterilkan ose dengan nyala spiritus, selanjutnya lakukan hal yang sama dari tahap f sampai tahap g terhadap semua tabung MPN yang positif. Apabila hasilnya negatif maka penelitian tidak dilanjutkan.

\section{Model Pengolahan Air Sungai secara Slow Sand Filter}

Metode Pengolahan air menggunakan filter saringan pasir lambat yang terbuat dari beberapa lapisan, yaitu lapisan pertama batu kerikil/koral dengan tinggi $10 \mathrm{~cm}$, lapisan kedua busa, lapisan ketiga pasir dengan tinggi $15 \mathrm{~cm}$. Lapisan keempat arang $(8 \mathrm{~cm})$ dan lapisan kelima pasir. Lapisan keenam ijuk $(5 \mathrm{~cm})$. Lapisan terakhir busa. Tahapan pembuatan tempat untuk filter-filter 
penting dilakukan sebelum menjernihkan air sungai. Tempat tersebut digunakan sebagai saringan disetiap lapisan bahan sebelum air dikeluarkan melalui kran sebagai saluran air. Semua media dimasukkan ke dalam cashing slow sand filter dengan tinggi minimal $60 \mathrm{~cm}$ maksimal $120 \mathrm{~cm}$. Selanjutnya memasukkan semua bahan filter seperti busa, ijuk, pasir, arang, dan batu koral/kerikil kedalam tempat tersebut. Jika semua filter sudah tersusun sesuai fungsinya kemudian memasukkan air kedalam wadah yang sudah berisi susunan filter-filter. Selanjutnya diamkan sekitar \pm 15 menit sebagai proses penjernihan alami, kemudian buka kran dan alirkan. Pertama-tama air masih keruh, akan tetapi lama-kelamaan dan terus menerus dialirkan, airnya akan berubah menjadi bening atau tidak keruh. Air yang tidak keruh tersebut bisa dipergunakan untuk kebutuhan sehari-hari, tetapi tidak dianjurkan untuk air minum.

\section{HASIL DAN PEMBAHASAN}

\subsection{Penerapan Metode Slow Sand Filter dalam pengolahan air sungai}

Pendekatan pengembangan masyarakat berbasis lingkungan sebagai bentuk partisipasi kelompok ibu melibatkan fasilitator diawali dengan pengenalan wilayah (mapping) menggunakan metode PRA (Participation Rural Appraisal) diperoleh data jumlah penduduk Pekapuran Raya sebesar 4264 jiwa, dimana sebagian penduduk bermukim dibantaran sungai Pekapuran Raya. PRA yang dikembangkan oleh Robert Chambers menyatakan bahwa metode ini mendorong masyarakat untuk turut serta meningkatkan pengetahuan dan menganalisis kondisi wilayah masyarakat sendiri,agar dapat membuat rencana dan tindakan pemecahan masalah dengan cara berkumpul, membahas permasalahan yang harus dilakukan secara bersama [8].

Kecamatan Banjar Timur terbagi menjadi tujuh wilayah termasuk daerah aliran sungai (DAS) yang bermuara di Sungai Barito dan Sungai Martapura [1]. Salah satu sungai yang jumlah penduduk padat dengan hunian disepanjang sungai adalah Sungai Antasan Segra Banjarmasin karena wilayah pemukiman berada dijalur transportasi pedagang yang berjualan di Pasar Binjai. Permasalahan yang ditemukan berdasarkan analisis PRA sebelum intervensi pengolahan air sungai, yaitu peningkatan pemahaman masyarakat khususnya kelompok ibu tentang sanitasi lingkungan terutama berkaitan dengan penyedian air bersih, ketersediaan jamban, pengolahan airlimbah, pembuangan tinja, pembuangan sampah, dan pencemaran air sungai serta dampaknya terhadap kesehatan.Penekanan konsep pendidikan berbasis masalah terhadap kelompok ibu diharapkan mampu mencegah pencemaran dibadan sungai, mengeliminasi perilaku membuang sampah kesungai secara langsung dengan modifikasi model pengolahan lingkungan secara sederhana mudah, praktis, dan berkelanjutan, diharapkan mampu mengatasi permasalahan tersebut secara optimal oleh masyarakat dan untuk masyarakat sendiri.

Hasil analisis diagnosa komunitas menunjukkan bahwa sebagian besar masyarakat tidak peduli akan bahaya dari pembuangan sampah 
disungaisebesar $82 \%$ dan sebesar $94,74 \%$ warga di sepanjang sungai tersebut masih menggunakan air sungai untuk keperluan sehari-hari seperti buang air besar, mandi, sikat gigi, cuci peralatan masak dan bahan makanan langsung dari sungai, meskipun air terlihat keruh, kecoklatan dan terdapat banyak sampah yang menumpuk dibawah rumah warga terutama disepanjang bantaran sungai.Masyarakat juga mengeluhkan kualitas air sungai tersebut. Keadaan ini sangat disayangkan karena beberapa tindakan masyarakat yang tidak perduli dengan sungai menyebabkan air sungai kotor dan berbau.

Kondisi ini diperparah dengan adanya Limpasan air hujan yang membawa sampah dari hulu ke hilir maupun pusat-pusat kegiatan pasar, aktivitas industri dan rumah tangga dan Pelbagai jenis sampah seperti enceng gondok, ranting, dahan kayu dan plastik, botol minuman, bangkai binatang berserakan di sungai, menyebabkan terjadinya pencemaran air dan tanah yang berdampak keseimbangan lingkungan terganggu [3,9]. Penggunaan sungai telah berubah fungsi sebagai septick tank communal dan dijadikan sebagai tempat pembuangan sampah akhir oleh warga pinggiran sungai. Akibatnya sungai kehilangan fungsinya sebagai jalan transportasi, wisata, dan drainase alami kota. Hasil studi Indonesia Sanitation Sector Development Program (ISSDP) tahun 2006 terdapat $47 \%$ masyarakat masih berperilaku buang air besar ke sungai, sawah, kolam, kebun dan tempat terbuka [10].

Proses penyaringan air menggunakan metode slow sand filter merupakan salah satu alternatif pengolahan air secara sederhana dan mudah digunakan yang dapat diterapkan oleh kelompok ibu di Pekapuran Raya. Media yang digunakan dalam pengolahan air tersebut seperti, pasir $(15 \mathrm{~cm})$, arang aktif $(8 \mathrm{~cm})$, sabut kelapa (Ijuk) $(5 \mathrm{~cm})$ dan Batu koral/kerikil $(10 \mathrm{~cm})$ yang dilakukan berselang seling dan dibuat busa penyangga agar mekanisme pengolahan lebih mudah dilakukan. Bahan yang digunakan juga tersedia cukup banyak disekitar rumah warga.

Tingginya minat masyarakat saat kegiatan berlangsung terlihat dari gambar 1. Hasil pengukuran fisik pengolahan menggunakan slow sand filter. dengan cara membandingkan sebelum dan setelah pengolahan, terbukti bahwa tingkat kekeruhan air sungai dari berwarna kecokelatan menjadi bening setelah penyaringan, artinya model ini sudah cukup memadai utk digunakan oleh masyarakat. memudahkan Hasil pengolahan ini diharapkan memudahkan masyarakat memanfaatkan air sungai menjadi air bersih, karena lebih sederhana, murah, serta aman, jika digunakan untuk keperluaan sehari-hari seperti mencuci, mandi dan aktivitas lainnya. Banyaknya kelompok ibu yang bertanya dan terlihat antusias saat berdiskusi tentang proses pengolahan air dari tahapan awal hingga akhir penyaringan air tersebut, terbukti dari 38 responden sebesar $89 \%$ menyebutkan bahwa kegiatan ini bermanfaat dan dapat diterapkan disetiap rumah khususnya warga yang menggunakan air sungai untuk keperluan sehari-hari. 


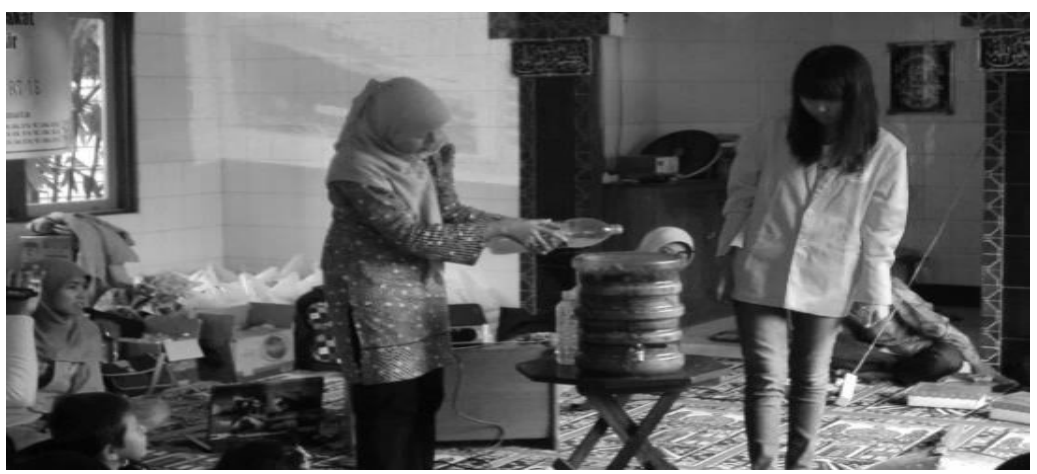

Gambar 1. Proses penerapan metode slow sand filter

\subsection{Hasil Pengukuran MPN Coliform pada air Sungai Pekapuran}

Kualitas air yang memenuhi persyaratan biologis adalah air yang di dalamnya tidak terdapat mikroba seperti virus, bakteri, jamur ataupun pathogen lainnya yang dapat berakibat buruk bagi kesehatan masyarakat. Golongan Coliform adalah golongan yang termasuk bakteri batang gram negatif, yang tidak membentuk spora dan fakultatif anaerob, yang tumbuh dengan adanya garam empedu dan memfermentasikan laktosa dengan menghasilkan asam. E.coli adalah salah satu grup Coliform yang dapat memfermentasikan laktosa dengan membentuk asam dan gas pada suhu $44^{\circ} \mathrm{C}$, indol positif, tidak dapat menggunakan citrat, menghasilkan asam dari manitol pada $37^{\circ} \mathrm{C}$, MR positif, VP negatif [4].

Berdasarkan hasil observasi lapangan juga menunjukkan adanya kebiasaan anak-anak menggunakan sungai sebagai tempat bermain (berenang), meskipun air terlihat kotor dan banyak sampah berbahaya seperti pecahan kaca, kayu, paku, plastik yang terminum terus menerus akan membahayakan kesehatan anak di Pekapuran Raya.Salah satu aktivitas rutin masyarakat melakukan kebiasaan BAB disungai sebesar 89,47\%, hal ini disebabkan sebagian besar responden tidak memiliki jamban sendiri. Sehingga tinja tidak di kelola dengan baik, dimana tinja merupakan sumber penyakit terutama penyakit diare.

Hasil pemeriksaan MPN Coliform pada air sungai Pekapuran Raya Banjarmasin menunjukkan hasil positif $100 \%$ sebesar $>240 / 100 \mathrm{ml}$ sampel air (seri 7 tabung). Keadaan tersebut menunjukkan bahwa air sungai sudah tercemar oleh bakteri Coliform, sehingga tidak memenuhi syarat kesehatan. Cemaran dapat berasal dari kotoran kotoran manusia, sampah dari Pasar Binjai dan limbah domestic yang langsung dibuang kesungai tersebut. Hasil penelitian terhadap sungai Martapura yang dilakukan oleh Fakultas MIPA Universitas Lambung Mangkurat 2007, ditemukan bahwa bakteri Eshericia coli sebanyak 1,6 juta per $100 \mathrm{ml}$ air. Jumlah ini melebihi dari ambang baku mutu yang dipersyaratkan untuk air bersih yaitu $100 \mathrm{sel} / 100$ mili liter air [5].

Menurut Rolandus (2010) menyatakan bahwa ada pengaruh perilaku mengkonsumsi air sungai terhadap kejadian diare dapat dikatakan bahwa orang yang mengkonsumsi air minum yang belum dimasak memiliki resiko 2,625 kali lebih besar untuk terkena diare dibandingkan orang yang mengkonsumsi air yang sudah masak [12]. Hasil penelitian ini juga didukung oleh kumarijati (2006) dan suprapti (2003) bahwa ada hubungan perilaku konsumsi air yang sudah dimasak 
dengan kejadian diare. Sedangkan menurut Eman (2008) kebiasaan memasak atau merebus air sampai benar-benar mendidih untuk memastikan air sudah steril adalah salah satu alternatif penting dalam mencegah penyakit diare karena ditemuakan bahwa dalam 1 gr tinja mengandung 10 juta virus dan 1 juta bakteri [13]. Pentingnya menerapkan Perilaku hidup bersih dan sehat melalui peningkatan kesadaran masyarakat menjaga lingkungan perairan khususnya sungai, serta pelaksanaan regulasi yang tepat melalui dukungan dan kerjasama lintas sektor seperti Puskesmas, Dinas Kebersihanmaupun instansi pemerintah setempat agar lebih mengawasi keberlanjutan program sanitasi lingkungan disepanjang aliran sungai, sehingga penurunan beban pencemar akibat limbah maupun sampah ke Badan air sehingga penurunan tingkat penularan penyakit melalui air pada kelompok masyarakat yang beresiko

\section{SIMPULAN}

Berdasarkan penelitian yang dilakukan menunjukan bahwa penerapan model pengolahan air sungai dengan metode slow sand filter yang sederhana, murah, efisien,dan aman bagi masyarakat mampu meningkakan kualitas fisik air sungai, terlihat dari perubahan warna air sungai dari kecoklatan menjadi bening.Hasil pengukuran MPN Coliform pada air sungai Pekapuran Banjarmasin positif terdapat bakteri sebesar > 240/ $100 \mathrm{ml}$ sampel.

\section{SARAN}

Perlu dilakukan pembinaan masyarakat berkelanjutan melalui gerakan pengolahan air sungai menggunakan berbagai modifikasi metode slow sand filteryang terus dikembangkan dan diaplikasikan sebagai alternatif solusi mengurangi pencemar dibadan sungai.

\section{DAFTAR PUSTAKA}

[1] Kecamatan Banjarmasin Timur, 2009. Laporan Tahun Kecamatan Banjarmasin Timur Kelurahan Pekapuran Raya Banjarmasin. Potensi Desa Dan Kelurahan Pekapuran Raya Banjarmasin. Banjarmasin: Kecamatan Banjarmasin Timur.

[2] Anonim, 2004. Kota Seribu Sungai Seribu Masalah. Forum Walhi. http://info@walhi.or.id.diakses tanggal 04 Januari 2018.

[3] Anonim, 2007. Banjarmasin Terkotor,420 Meter ${ }^{3}$ Sampah Telah TerangkatKCM. Forum Walhi. http://wwwkompas.com.diakses2 Februari 2018.

[4] Hiswani, 2007. Diare Merupakan Salah Satu Masalah Kesehatan Masyarakat Yang Kejadiannya Sangat Erat Dengan Keadaan Sanitasi Lingkungan. Sumatera Utara : FKM Universitas Sumatera Utara.

[5] Muhlisin, Ahmad, 2004. Kualitas Bakteriologi Air dan Perilaku Kesehatan Di Kecamatan Banjarmasin Utara ; Dalam Kaitan Angka Kejadian Diare : Penelitian Observasional Laboratoris. Surabaya : Airlangga University 
[6] Dinas Kesehatan, 2008. Laporan Tahunan Dinas Kesehatan Provinsi Kalimantan Selatan tahun 2008. Banjarmasin : Dinas Kesehatan Kalimantan Selatan.

[7] Murti, B. (2010). Desain dan ukuran sampel untuk penelitian kuantitatif dan kualitatif di bidang kesehatan (2nd ed., pp. 31-57). Yogyakarta: Gadjah Mada Uniersity Press. Retrieved from http://www/gmup.um.ac.id

[8] Anonym. PRA (Participatory RuralAppraisal) Sebagai Pendekatan/metode Pelaksanaan Konsep pemberdayaan Masyarakat. www.kmsgroups.com.

[9] Putro gurendro dan Blandina, 2005. Hubungan Perilaku Hidup Bersih dan sehat ibu dan penggunaan sarana air bersih terhadap kejadian diare pada balita. Bidang Penelitian dan Pengembangan RSU Dr Soetomo 2005:(7) 2: 66-73.

[10] Keputusan Menteri Kesehatan RI, 2008. Tentang Strategi Nasional Santasi Total Berbasis Masyarakat Nomor 852/Menkes/SK/IX/2008. Jakarta :Departemen Kesehatan RI.

[11] .Ayu Ratu, dkk. Analisis mikrobiologi escherichia coli o157:h7 Pada hasil olahan hewan sapi dalam proses produksinya. Departemen Gizi Kesehatan Masyarakat, Fakultas Kesehatan Masyarakat, Universitas Indonesia. Jurnal Makara, Kesehatan, vol. 9, no. 1, juni 2005: 23-28.

[12] Rolandus V. Agas, dkk, 2009. Hubungan Perilaku Masyarakat dan Sanitasi Sumur Gali Terhadap Kejadian Diare Di Keluarahan Belo Wilayah Kerja Puskesmas Sikauman Kota Kupang.Undana : FKM.

[13] Eman, T., 2008. Cara Aman Konsumsi Air Minum. Jakarta : Republika Online, www.Gizi.net.com. Diakses 30 September 2010. 